giao thông (63.6\%). Đăc điểm lâm sàng chính là đau $(100 \%)$ và hạn chế vận động cổ $(87.8 \%)$, rối loạn cảm giác(39.3\%). Tổn thương thường gặp nhất là gãy C2 (66.7\%), không có trường hợp nào gãy lồi cầu chẩm $(\mathrm{C} 0)$.

\section{TÀI LIÊU THAM KHẢO}

1. Herkowitz, H.N., et al., Rothman-Simeone The Spine E-Book: Expert Consult. Vol. 1. 2011: Elsevier Health Sciences.

2. Nguyển Trọng Hiếu và cs, Đă̆c điểm lâm sàng và cận lâm sàng chấn thương cột sống cổ $\mathrm{C} 1-\mathrm{C} 2$,
Tạp chí Y học thực hành, số 9/2011, tr.77 - 79.

3. Nguyễn Viết Lực, Nguyển Lê Bảo Tiến, và CS., Đặc điểm lâm sàng và cận lâm sàng của bệnh nhân chấn thương cột sống cổ cao, Tạp chí Y học Viêt Nam, số 2 - 2021, tr $207-209$.

4. Hà Kim Trung, Nghiên cứu chẩn đoán và phẫu thuât chấn thương côt sống cố có tổn thương thần kinh tại Bệnh viện Việt Đức, Luận án Tiến sĩ y học, Đai hoc Y Hà Nổi, 2005.

5. Vũ̃ Văn Cường, Nghiên cứu ứng dụng kỹ thuât harms cải tiến trong điêu trị chân thương mất vững C1-C2. Luận án Tiến sĩ Y học, Đại học Y Hà Nội, 2018.

\title{
ĐÁNH GIÁ HOẠT TÍNH CHỈNH SỬA GEN BCL11A TRÊN THỰC NGHIÊMM CỦA PROTEIN CAS9 TÁI TỔ HỢP, ĐỊNH HƯỚNG ỨNG DỤNG ĐIỀU TRI BỆNH HỒNG CẦU LIỀM
}

\section{TÓM TẮT}

Mục tiêu: Thiết kế phức hợp rCas9/sgRNA để chỉnh sửa gen $B C L 11 A$ tách dòng vào plasmid pJET1.2 trong điêu kiên in vitro nhằm đánh giá hoạt tính protein Cas9 tái tổ hợp và định hướng ứng dụng điều tri bênh hồng câu liềm. Đối tượng và phương pháp: Khuếch đại vùng Enhancer của gen $B C L 11 A$ bằng phản ứng $P C R$, phân tích so sánh trình tự với DNA của người Việt Nam. Thiết kế chuỗi đơn RNA dẫn đường (sgRNA) và tao phức hợp rCas9/sgRNA. Thử nghiệm hoạt tính phức hợp trêngen BCL11A đã được tách dòng vào plasmid pJET1.2 trong điều kiên in vitro. Kết quả: Phức hợp rCas9/sgRNA tổng hợp được đã cắt vùng enhancer của gen BCL11Atrên in vitro thành 2 sản phẩm có kích thước khoảng 240bp. Giải trình tự gen sảm phẩm $\mathrm{PCR}$ cho thẩy phức hợp rCas9/sgRNA đã cắt vùng gen enhancer GATAA của BCL11A tại vị trí cách vùng PAM 3 cặp nucleotide theo đúng tính toán lý thuyết. Kết luận: Protein Cas9 tái tổ hợp có hoạt tính tương tự protein Cas9 tự nhiên và phức hợp rCas9/sgRNAcần được tiếp tục nghiên cứu đêứng dụng trong chỉnh sửa gen $B C L 11 A$ điều trị bệnh hồng câu liềm trên lâm sàng.

Tư khóa: Hệ thống CRISPR/Cas9, bệnh hồng cầu liềm, chỉnh sửa gen

\section{SUMMARY}

EVALUATION OF RECOMBINANT CAS9

PROTEIN IN-VITRO EDITING OF BCL11A GENE FOR CURING SICKLE CELL DISEASE

Objective: To design a rCas9/sgRNA complex for editting of BCL11A gene in in-vitro and evaluation of

*Bệnh viện Quân y 103

Chịu trách nhiệm chính: Đỗ Như Bình

Email: nhubinh.do@vmmu.edu.vn

Ngày nhận bài: 25/4/2021

Ngày phản biên khoa hoc: 25/5/2021

Ngày duyệt bài: 17/6/2021
Đỗ Như Bình*

recombinant Cas9 protein activity for orientational applying in the treatment of sickle cell disease. Materials and methods: Amplification of the enhancer region of the BCL11A gene by PCR, sequencingand comparing with Vietnamese DNA. Design a single-strand guide RNA (sgRNA) and create an rCas9/sgRNA complex. Evaluate the activity rCas9/sgRNA complex on the BCL11A gene cloned into the pJET1.2 plasmid under in vitro condition. Results: The synthesized rCas9/sgRNA complex has cleaved the enhancer region of BCL11A gene in in-vitro into two products with the size of approximately $240 \mathrm{bp}$. The gene sequencing showed that the rCas9/sgRNA complex cut exactly the GATAA enhancer region of BCL11A gene at a position of 3 nucleotides away from the PAM region according to theoretical calculations. Conclusion: Recombinant Cas9 protein had a similar activity as natural Cas9 protein and rCas9/sgRNA complex needs to be further studied for application in BCL11A gene editing to treat sickle cell disease in clinical practice.

Keywords: CRISPR/Cas9 system; sickle cell disease; gene editing

\section{I. ĐĂT VẤN ĐỀ}

Công nghê chỉnh sửa gen sử dụng CRISPR/Cas9 là một trong những tiến bô vượt bậc trong lĩnh vực sinh học phân tử,đã và đang được ứng dụng rộng rãi trong các lĩnh vực từ sinh học, nông nghiệp, y học. [1],[3]. Trong lĩnh vực y học, các nhà khoa học đã ứng dụng công nghệ CRISPR để chữa các bệnh di truyên [5],[6]. Hệ thống CRISPR/Cas9 bao gồm 2 thành phân: enzyme Cas9 nuclease và RNA dẫn đường (sgRNA). Nhờ đoạn trình tự bổ sung của RNA dẫn đường với trình tự đích mà phức hợp này có thể tìm thấy vị trí cân chỉnh sửa trên hệ gen.Để có thể hoạt động, hệ thống CRISPR còn yêu câu 
một trình tự ngắn từ 2-5 nucleotides trên DNA đích được gọi là protospacer associated motif (PAM) ngay sau đoạn bổ sung của RNA dẫn đường (đối với CRISPR/Cas9 của vi khuẩn S.pyogenes thì trình tự này là $5^{\prime}-\mathrm{NGG}$, trong đó $\mathrm{N}$ là bất kỳ nucleotide nào). Khi phức hợp Cas9 và guide RNA bám vào trình tự đích, enzyme Cas9 sẽ dùng 2 tiểu phần $\mathrm{HNH}$ và RuVC của mình để cắt đoạn DNA trên cả 2 mạch tại vị trí nucleotide thứ 3-4 phía trước PAM [4],[7].

Thiếu máu hồng cầu hình liềm là một bệnh nă̆ng do cơ thể tạo ra những tế bào hồng cầu có hình liềm. Nguyên nhân là do đột biến xảy ra ở vị trí thứ 6 trên chuỗi beta globin thuộc phân tử hemoglobin, gây biến đổi axit glutamic ưa nước thành axit valine ky. nước. Việc điều trị bệnh hồng cầu hình liềm hiện nay chủ yếu sử dụng các liệu pháp như truyền máu, ghép tế bào gốc hay ghép tủy xương. Tuy nhiên, liệu pháp này cũng có nhiều biến chứng nguy hiểm và chỉ thực hiện được ở những trung tâm huyết học lớn và hiện đại. Sự ra đời công nghệ CRISPR/Cas9 đã cho phép các nhà khoa học xây dựng những liệu pháp gen để sửa chữa các sai hỏng trong DNA bộ gen trong các bệnh lý di truyền, trong đó có bệnh thiếu máu hồng cầu hình liềm. Có 3 liệu pháp gen được đề cập trong chữa bệnh hồng cầu hình liềm là sửa chữa lại đột biến trên chuổi beta-globin, thay thế đoạn gen bị đột biến và tăng sản xuất hồng cầu bào thai bằng cách gây đột biến gen hoặc bất hoạt enhancer gen điều hòa tổng hợp protein $B C L$ (B-cell lymphoma/ leukemia) $11 A$ [5]. Trong nghiên cứu này, chúng tôi sử dụng protein tái tổ hợp Cas9 (rCas9) được tổng hợp trong E.coli BL21/DE3 từ nghiên cứu trước, tiến hành thiết lập hệ thống rCas9/sgRNA để chỉnh sửa gen $B C L 11 A$ trong điều kiện in vitro nhằm đánh giá hoạt tính protein Cas9 tái tổ hợp và định hướng ứng dụng điều trị bệnh hồng cầu liềm.

\section{II. ĐỐI TƯợNG VÀ PHƯƠ'NG PHÁP NGHIÊN CỨU}

1. Đối tượng: Gen $B C L 11 A$ đã được tách dòng vào plasmid $\mathrm{pJET} 1.2$ và hệ thống CRISPR/rCas9 hay rCas9/sgRNA.

\section{Hóa chất và thiết bị nghiên cứu}

- Hóa chất: cặp mồi BCL11A_Seq_F: 5'GAGAGTGCAGACAGGGGAAG-3'

BCL11A_Seq_R: 5'-GGCAGCTAGACAGGACTTGG3'; EnGen sgRNA Synthesis Kit, S. pyogenes (New England Biolabs); MEGAclear ${ }^{\mathrm{TM}}$ Transcription Clean-Up Kit (Thermo Fisher Scientifics); QIAquick PCR purification kit (Qiagen); gel Agarose...
- Thiết bị nghiên cứu chính: Các thiết bị sử dụng bao gồm máy chu kỳ nhiệt 96 mẫu (Ëpendorf, Đức); Máy soi chụp ảnh gel (Gensnap, Mỹ); Bộ điện di DNA Horrizontal mini (CBS Scientific, Mỹ); phần mềm CHOP CHOP; Primer3...

\section{3. Địa điểm, thời gian nghiên cứu}

- Địa điểm thí nghiệm: Viện Nghiên cứu Y dược học Quân sự, Học viện Quân y.

- Thời gian nghiển cứu: từ tháng 08/2019 đến 09/2020

\section{Phương pháp nghiên cứu}

> Thiết kế mồi PCR khuếch đại vùng Enhancer của gen BCL11A

- Sử dụng phần mềm Primer3 để thiết kế mồi $P C R$ khuếch đại vùng Enhancer của gen $B C L 11 A$

- Tối ưu hóa phản ứng $P C R$ khuếch đại vùng Enhancer của gen BCL11A. Để tối ưu hóa phản ứng PCR khuếch đại vùng Enhancer gen $B C L 11 A$ của 2 mẫu DNA người Việt Nam với hai mồi đã thiết kế, chúng tôi tiến hành thử nghiệm ba nhiệt độ bắt cặp là $59,62,5$ và $66^{\circ} \mathrm{C}$. Khuểch đai vùng gen đích ở nhiệt độ tối ưu và gửi đi giải trình tự.

- Phân tích trình tự vùng Enhancer của gen BCL11A từ 2 mẫu DNA của người Việt Nam khỏe mạnhvới trình tự gen trong ngân hàng dữ liệu GenBank.

> Thiết kế sgRNA

- Sử dụng công cụ CHOP CHOP: http://CHOPCHOP.cbu.uib.no/index.php hoặc Benchling: https://benchling.com/academicthiết kế trình tự sgRNA đặc hiệu cho vùng gen lân cận vùng Enhancer GATAA của gen BCL11A.

- Lựa chọn trình tự mục tiêu, xác định và phân loại các vùng mục tiêu phù hợp. Các thông số được thiết lập giúp tính toán cho từng mục tiêu dự định. Ngoài ra, công cụ còn có thể chọn trình tự gRNA bằng cách xác định trình tự 20 bp bất kỳ với đầu $5 \phi-N G G$.

> Thử nghiệm hoạt tính chỉnh sửa gen BCL11A trên in vitro của CRISPR/rCas9

Hoạt tính của protein rCas9 sẽ được đánh giá bằng cách sử dụng phức hợp rCas9/sgRNA để phân cắt đoạn gen mang vùng gen enhancer của $\mathrm{BCL11A}$ đã được tách dòng vào plasmid $\mathrm{pJET1.2.}$ Kết quả điện di trên gel và giải trình tự sẽ cho phép đánh giá tính chính xác và hiệu quả của phản ứng cắt gen đích in vitro.

5. Xử lý số liệu: Các dữ liệu sinh học được xử lý bằng các phần mềm tin sinh chuyển dụng như Bioedit, CLUSTALW để làm sạch và thu nhận dữ liệu nghiên cứu.

\section{KẾT QUẢ NGHIÊN CỨU VÀ BÀN LUÂN}

1. Kết quả khuếch đại vùng Enhancer 
của gen BCL11A. Qua kết quả điện di sản phẩm PCR ở hình 1, nhận thấy ở tất cả các nhiệt độ đã thử nghiệm $\left(59,62,5\right.$ và $\left.66^{\circ} \mathrm{C}\right)$ đều thu được một băng sản phẩm duy nhất và rõ nét. Tuy nhiên, ở nhiệt độ $62,5^{\circ} \mathrm{C}$, cho băng sản phẩm rõ nhất. Do vậy, nhiệt độ gắn mồi tối ưu để khuếch đại vùng Enhancer của gen $B C L 11 A$ từ 2 mẫu DNA người là $62.5^{\circ} \mathrm{C}$.

1: âm tính; 2,3: nhiệt độ gắn mồi $59^{\circ} \mathrm{C}$; 4 : HighRanger $1 \mathrm{~kb}$ DNA Ladder (Norgen); 5,6: nhiệt độ gắn mồi $62,5^{\circ} \mathrm{C} ; 7,8$ : nhiệt độ gắn mồi $66^{\circ} \mathrm{C}$

Nhân xét: Kết quả so sánh trình tự vùng gen đích của 2 mẫu DNA đã sử dung trong nghiên cứu này với trình tự gen $\mathrm{BCL11A}$ trong ngân hàng dữ liệu GenBank cho thấy vùng gen đích có tính bảo thủ khá cao. Đăc biêt là không có các đột biến xung quang vùng Enhancer "GATAA" (Hình 2)

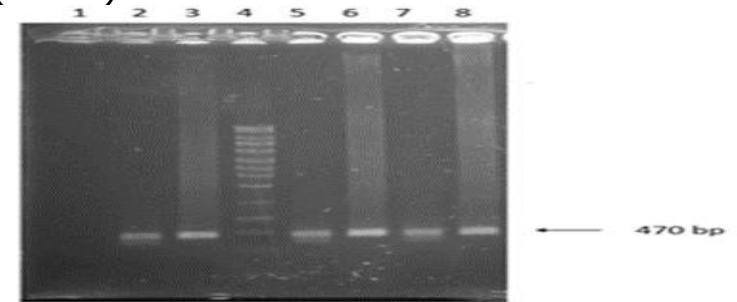

Hình 1. Tối ưu hóa nhiệt độ gắn mồi phản ứng PCR khuếch đai vùng Enhancer của gen BCL11A từ 2 mẫu DNA người
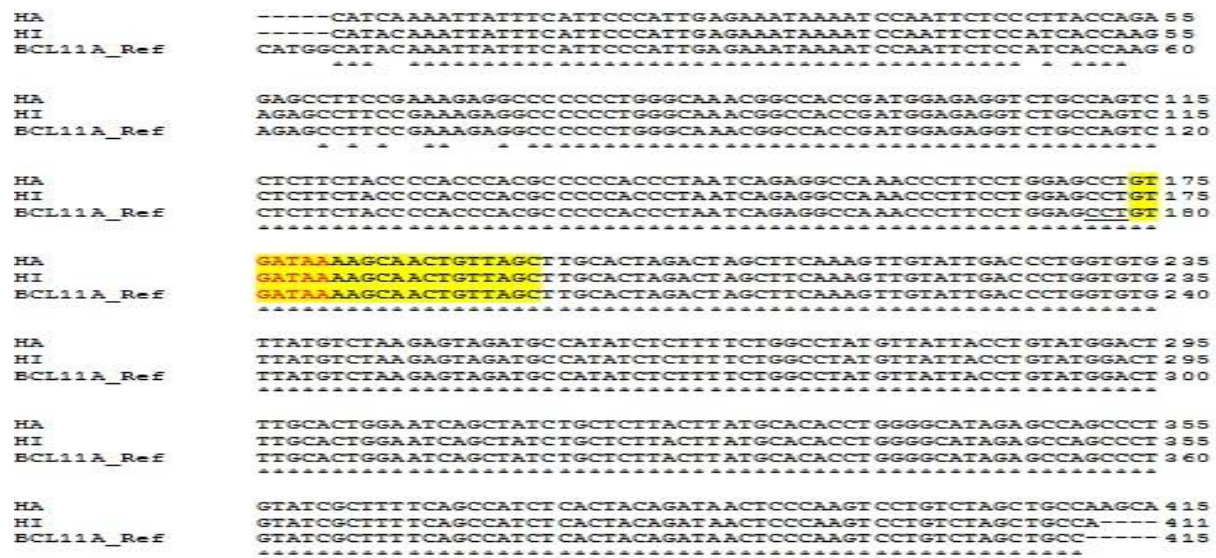

Hình 2. So sánh trinh tự vùng Enhancer của gen BCL11A giữa 2 mẫu DNA được sử dụng trong nghiên cứu này với trinh tự trong ngân hàng dữ liệu GenBank bằng ClustalW.

2. Kết quả thiết kế sgRNA. Sử dụng phần mềm CHOPCHOP

tai http:// CHOPCHOP.cbu.uib.no/ index.php để thiết kê trình tự sgRNA đặc hiệu cho vùng gen lân cận vùng Enhancer GATAA thu được trình tự là CTAACAGTTGCTTTTATCAC, phức hợp rCas9/sgRNA sẽ nhận biết và cắt tại vị trí giữa $\mathrm{G}$ và $A$ trong trình tự Enhancer GATAA của gen $\mathrm{BCL} 11 \mathrm{~A}$. Về khả nắng cắt "off-target", trình tự sgRNA nói trên sẽ có thể lai với 6 trình tự nằm trên các chromosome khác nhau với số lượng mismatch là 3 nucleotide. Do vậy, khả năng cắt "off-target" khi dùng gRNA đã thiết kế là thấp.

Theo hướng dần của sinh phẩm EnGen sgRNA Synthesis Kit, S. pyogenes (New England Biolabs), trình tự oligonucleotide tổng hợp sgRNA bằng phiên mã in vitro là:

TTCTAATACGACTCACTATAGCTAACAGTT GCTTTTATCACGTTTTAGAGCTAGA

Trong đó: TTCTAATACGACTCACTATA: vùng trình tự T7 promoter

G: khởi đầu quá trình phiên mã
CTAACAGTTGCTTTTATCAC: trình tự nhận biết điểm cắt

GTTTTAGAGCTAGA: trình tự overlap với guideRNA scaffold

Với cách thiết kế như vậy, sgRNA có trình tự sau khi tổng hợp bằng phiên mã in vitro là: GCUAACAGUUGCUUUUAUCACGUUUUAGAG CUAGAAAUAGCAAGUUAAAAUAAGGCUAGU CCGUUAUCAACUUGAAAAAGUGGCACCGAG UCGGUGCUUUU

Với oligonucleotide đã thiết kế, tiến hành tổng hợp sgRNA bằng sinh phẩm EnGen sgRNA Synthesis Kit, S. pyogenes (New England Biolabs) theo quy trình nhà sản xuất. Sau khi tinh sạch bằng MEGAclear ${ }^{\mathrm{TM}}$ Transcription CleanUp Kit (Thermo Fisher Scientifics), tiến hành điện di sản phẩm trên gel Agarose.

Kết quả ở hình 3 cho thấy xuất hiện 2 băng sáng trên gel với kích thước lần lượt là khoảng 100 và $200 \mathrm{~b}$. Theo tính toán lý thuyết, sgRNA được tổng hợp có kích thước 120b. Như vậy, đã tổng hợp thành công sgRNA vàtheo dự đoán của 
chúng tôi, băng có kích thước 200b sẽ tương ứng với cấu trúc bậc 2 của sgRNA.

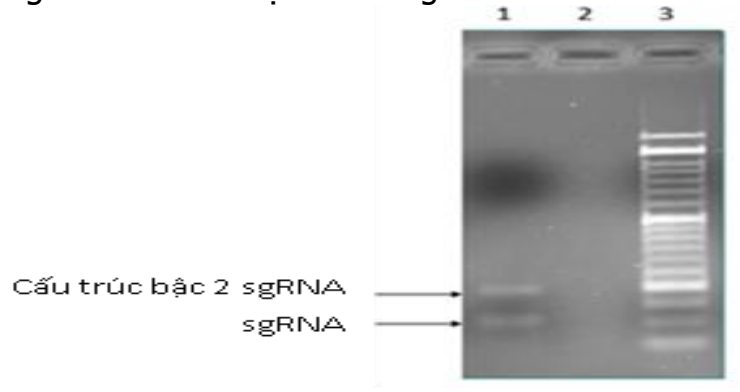

Hình 3. Kết quả điện di sản phẩm phiên mã in vitro bằng sinh phẩm EnGen sgRNA Synthesis Kit, S. pyogenes (New England Biolabs)

1: sản phẩm tổng hợp sgRNA, 2: âm tính, 3: 50 bp DNA ladder (Bioland Scientifics)

3. Kết quả thử nghiệm cắt sản phẩm PCR chứa vùng Enhancer của gen BCL11A bằng phức hợp rCas9/sgRNA in vitro. Quy trình thử nghiệm cắt sản phẩm PCR chứa vùng gen đích bằng phức hợp rCas9/sgRNA in vitro được tiến hành theo khuyến cáo của $\mathrm{New}$ England Biolabs (https:// www.neb.com/ protocols/2014/05/01/ in-vitro-digestion-of-dnawith-cas9-nuclease-s-pyogenes-m0386). Sản phẩm của quá trình cắt được tinh sạch bằng QIAquick PCR purification kit (Qiagen) và được điện di trên gel agarose.

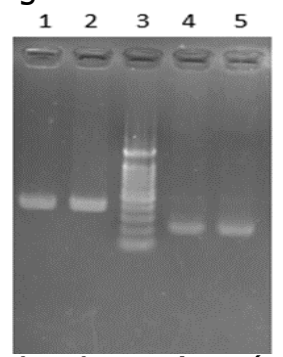

Hình 4. Kết quả thử nghiệm cắt sản phẩm $P C R$ khuếch đại vùng Enhancer gen BCL11A bằng phức hơp rCas9/sgRNA tự sản xuất

1,2: sản phẩm PCR trước khi cắt; 3: SiZer100 DNA Marker (iNtRON Biotechnology); 4,5: sản phẩm PCR sau khi cắt

Nhận xét: Kết quả điện di trên cho thây 2 sản phẩm cắt có kích thước khoảng 240bp, phù hợp với tính toán lý thuyết (236 và $234 b p$ ). Tuy nhiên, cần làm rõ điểm cắt trên đoạn gen đích bằng phương pháp giải trình tự để khẳng định hoạt tính và tính chính xác của phức hợp rCas9/sgRNA.

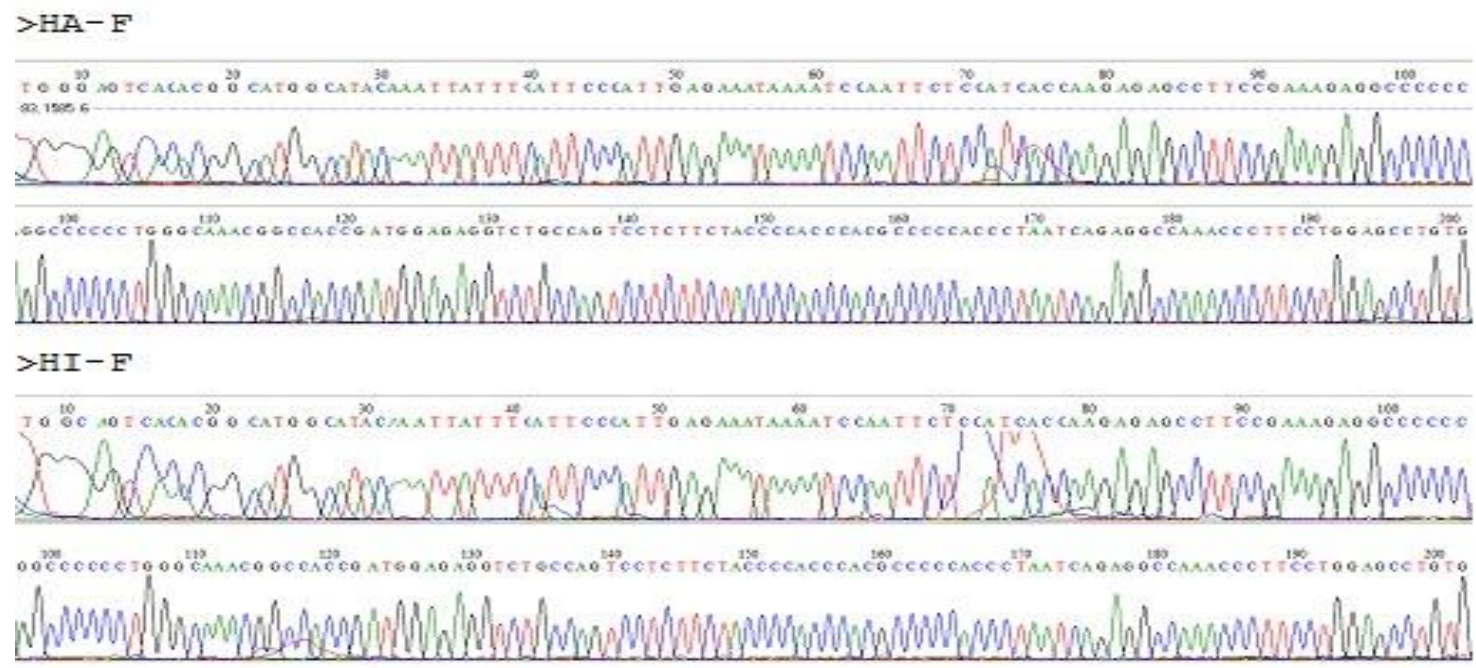

Hình 5. Kết quả giải trình tự sản phẩm cắt vùng enhancer gen BCL11A của mẫu DNA HA và HI bằng mồi BCL11A_Seq_F

Nhận xét: Kết quả giải trình tự với mồi $\mathrm{BCL} 11 \mathrm{~A} \_$Seq_F hai sản phẩm cắt bằng phức hợp rCas9/sgRnA cho thây các trình tự này được kết thúc bẳng đoạn CCTGGAGCCTGTG, trong đó trình tự CCT chính là đoạn đối ngẫu của trình tự PAM AGG. Như vậy, phức hợp rCas9/sgRNA tự sản xuất đã cắt vùng gen đích tại vị trí cách vùng PAM 3 cặp nucleotide, đúng như tính toán lý thuyết.

\section{KẾT LUẬN}

Qua các kết quả thu được ở trên chứng tỏ protein Cas9 tái tổ hợp tự sản xuất trong vi khuẩn E.coli có đầy đủ các hoạt tính như protein Cas 9 có nguồn gốc từ vi khuẩn Streptococcus pyrogen. Đông thời đã thiết kế và ứng dụng thành công phức hợp rCas9/sgRNA trong chỉnh sửa vùng enhancer của gen $\mathrm{BCL} 11 \mathrm{~A}$ trên invitro, 
mở ra định hướng ứng dụng trong điêu trị bệnh hồng câuu liềm trên lâm sàng.

\section{TÀI LIÊU THAM KHẢO}

1. Doudna JA \& Charpentier E (2014) Genome editing. The new frontier of genome engineering with CRISPR-Cas9. Science 346(6213):1258096.

2. George M.Church., et al.,(2016) CRISPR-Cas9 System: Opportunity and Concern, doi:10.1373/clinchem.2016.263186

3.Gilbert L.A et al. (2013) CRISPR-mediated modular RNA-guided regulation of transcription in eukaryotes. Cell 154, 442-451.
4. Harrison M.M et al., (2014) A CRISPR view of development. Genes Dev 28, 1,859-1,872.

5. Haydar Frangoul et al (2021). CRISPR-Cas9 Gene Editing for Sickle Cell Disease and $\beta$ Thalassemia. New England Journal of Medicine; 384 (3): 252 DOI: 10.1056/NEJMoa2031054

6. Platt RJ, et al. (2014) CRISPR-Cas9 knockin mice for genome editing and cancer modeling. Cell 159(2):440-455.

7. Ran FA, et al. (2013) Genome engineering using the CRISPR-Cas9 system. Nature protocols 8(11):2281-2308.

\title{
NGHIÊN CỨU ĐĂC ĐIỂM NANG THÂN MẮC PHẢI CỦA THÂNN CHỦ Ở BÊNH NHÂN SAU GHÉP THÂN
}

\author{
Nguyễn Văn Thuần", Phạm Quốc Toản ${ }^{2}$, Nguyễn Thanh Xuân ${ }^{2}$
}

\section{TÓM TẮT}

Mục tiêu: Đánh giá đặc điểm nang thân mắc phải của thận chủ ở bệnh nhân sau ghép thận. Đối tượng và phương pháp: 196 bênh nhân sau ghép thân được theo dõi tại Khoa Thận - lọc máu, Bệnh viển Quần y 103. Bênh nhân được khai thác các đặc điểm chung về tuổi, giới, thời gian lọc máu và khảo sát đặc điểm nang thân bằng siêu ẩm tai Khoa Siêu âm, Trung tâm Chẩn đoán hình ảnh, Bệnh viện Quân y 103. Kết quả: Tuổi tại thời điểm ghép thận còn rất trẻ, trung bình: 38,84 $\pm 9,96$; tỷ lệ nam/nữ là 2,8; thời gian lọc máu trung bình: 24,99 \pm 40,4 (tháng). Tỷ lệ bênh nhân có nang thân mắc phải ở thân chủ là $8,7 \%$. Tỷ lệ nang thận mắc phải tăng dân theo tuổi và thời gian lọc máu trong khi không có sự khác biệt về giới tính. Kết luận: Nghiên cứu đã đưa ra bằng chứng về tỷ lê nang thận chủ và một số yếu tố liên quan trên bệnh nhân sau ghép thận. quan

Tư khóa: Nang thận ,sau ghép thận, yếu tố liên

\section{SUMMARY}

CHARACTERISTICS OF ACQUIRED KIDNEY

CYSTS OF HOST KIDNEYS IN KIDNEY TRANSPLANT PATIENTS

Objective: To investigate characteristics of acquired kidney cysts of host kidneys in kidney transplant patients. Subjects and methods: 196 kidney transplant patients were treated at nephrology and dialysis department, military Hospital 103. They were consulted to find some related factors including ages, genders, length of time on dialysis prior to renal

${ }^{1}$ Học viện Quân y

²Bệnh viện Quân y 103

Chịu trách nhiêm chính: Nguyễn Văn Thuần

Email: levanquan2002@yahoo.com

Ngày nhận bài: 19/5/2021

Ngày phản biện khoa học: 16/6/2021

Ngày duyệt bài: 28/6/2021 transplantation. Then, they were screened for kidney cysts by abdominal ultrasound at ultrasound department, center of diagnostic imaging, military hospital 103. Results: Almost patients were young, mean ages: $38,84 \pm 9,96$; ratio of males/female was 2,8 ; length of time on dialysis prior to renal transplantation were long, mean duration: 24,99 \pm 40,4 months. Ratio of acquired cystic kidney in the host kidneys was 8,7. Ratio of patients with kidney cysts were positively correlated to ages and length of time on dialysis prior to renal transplantation but not to genders. Conclusion: the present study provided new evidence of ratios of acquired kidney cysts at the host kidneys and some related factors in kidney transplant patients

Keywords: Acquired kidney cysts of the host kidneys, kidney transplant, related factors

\section{I. ĐĂT VẤN ĐỀ}

Ghép thận thành công, thận ghép thay thế gần hoàn toàn chức năng thận chủ đã bị suy, giúp người bệnh hồi phục sức khỏe và chất lượng cuộc sống [1]. Tuy nhiên, sau ghép thận, bệnh nhân phải sử dụng thuốc chống thải ghép, là yếu tố làm tăng nguy cơ ung thư thân chủ sau ghé pthận. Biến chứng ung thư thận chủ ở người bệnh sau ghép thận cao hơn nhiều so với dân số nói chung. Sự hiện diện của nang thận mắc phải là yếu tố nguy cớ của ung thư thân chủ [2]. Mối liên quan giữa bệnh nang thận mắc phải và ung thư thận chủ ở bệnh nhân sau ghép thận đã được rất nhiều tác giả trên thế giới nghiên cứu trong nhiều thập kỷ qua [3]. Vì vậy, các tác giả cho rằng nên sàng lọc nang thận chủ bằng siêu âm trên những bệnh nhân ghép thận cũng như cân tiếp tục đánh giá nang thận mắc phải trên bệnh nhân sau ghép. Tại Việt Nam, số lượng bệnh nhân ghép thận còn chưa nhiêu, phân lớn bệnh nhân có thời gian sau ghép chưa dài nên 